\title{
Cytisus scoparius link - A natural antioxidant
} Raja Sundararajan1, Nazeer Ahamed Haja1, Kumar Venkatesan"1, Kakali Mukherjee ${ }^{1}$, Bishnu Pada Saha1, Arun Bandyopadhyay ${ }^{2}$ and Pulok Kumar Mukherjee*1

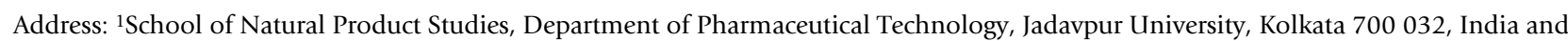
${ }^{2}$ Molecular Endocrinology Laboratory, Indian Institute of Chemical Biology, Kolkata 700 032, India
\end{abstract}

Email: Raja Sundararajan - sraja61@rediffmail.com; Nazeer Ahamed Haja - nangoo25@yahoo.co.in; Kumar Venkatesan - kumarvju@yahoo.com; Kakali Mukherjee - pulokm@vsnl.net; Bishnu Pada Saha - drbpsaha@yahoo.com; Arun Bandyopadhyay - arun0925@yahoo.com; Pulok Kumar Mukherjee* - Pknatprod@yahoo.co.in

* Corresponding author

Published: 16 March 2006

BMC Complementary and Alternative Medicine 2006, 6:8 doi:10.1 I86//472-6882-6-8

This article is available from: http://www.biomedcentral.com/l472-6882/6/8

(c) 2006 Sundararajan et al; licensee BioMed Central Ltd.

This is an Open Access article distributed under the terms of the Creative Commons Attribution License (http://creativecommons.org/licenses/by/2.0), which permits unrestricted use, distribution, and reproduction in any medium, provided the original work is properly cited.

\begin{abstract}
Background: Recent investigations have shown that the antioxidant properties of plants could be correlated with oxidative stress defense and different human diseases. In this respect flavonoids and other polyphenolic compounds have gained the greatest attention. The plant Cytisus scoparius contains the main constituent of flavone and flavonals. The present study was undertaken to evaluate the in vitro antioxidant activities of extract of aerial part of Cytisus scoparius.
\end{abstract}

Methods: The plant extract was tested for DPPH (I, I-diphenyl, 2-picryl hydrazyl) radical scavenging, nitric oxide radical scavenging, superoxide anion radical scavenging, hydroxyl radical scavenging, antilipid peroxidation assay, reducing power and total phenol content.

Results: The extract exhibited scavenging potential with $I C_{50}$ value of $I .5 \mu \mathrm{g} / \mathrm{ml}, 116.0 \mu \mathrm{g} / \mathrm{ml}$ and $4.7 \mu \mathrm{g} / \mathrm{ml}$ for DPPH, nitric oxide and superoxide anion radicals. The values were found to lesser than those of vitamin C, rutin, and curcumin, as standards. The extract showed $50 \%$ protection at the dose of $104.0 \mu \mathrm{g} / \mathrm{ml}$ in lipid peroxidation induced by $\mathrm{Fe}^{2+} /$ ascorbate system in rat liver microsomal preparation. There is decrease in hydroxyl radical generation with $\mathrm{IC}_{50}$ value of 27.0 $\mu \mathrm{g} / \mathrm{ml}$ when compared with standard vitamin $\mathrm{E}$. The reducing power of the extract depends on the amount of extract. A significant amount of polyphenols could be detected by the equivalent to $0.0589 \mu \mathrm{g}$ of pyrocatechol from I $\mathrm{mg}$ of extract.

Conclusion: The results obtained in the present study indicate that hydro alcoholic extract of aerial part of Cytisus scoparius is a potential source of natural antioxidants.

\section{Background}

Oxidative stress plays an important role in the pathogenesis of various diseases such as atherosclerosis, alcoholic liver cirrhosis and cancer etc $[1,2]$. Oxidative stress is initiated by reactive oxygen species (ROS), such as superox- ide anion $\left(\mathrm{O}_{2}^{-}\right)$, perhydroxy radical $\left(\mathrm{HOO}^{-}\right)$and hydroxyl radical ( $\left.\mathrm{HO}^{*}\right)$. These radicals are formed by a one electron reduction process of molecular oxygen $\left(\mathrm{O}_{2}\right)$. ROS can easily initiate the lipid peroxidation of the membrane lipids, causing damage of the cell membrane of 
phospholipids, lipoprotein by propagating a chain reaction cycle [3]. Thus, antioxidants defense systems have coevolved with aerobic metabolism to counteract oxidative damage from ROS. Most living species have efficient defense systems to prevent themselves against oxidative stress induced by ROS [4]. Recent investigations have shown that the antioxidant properties of plants could be correlated with oxidative stress defense and different human diseases like aging process etc [5-8]. In this respect flavonoids and other polyphenolic compounds have received the greatest attention [9].

The genus cytisus consists of about 70 species confined to the mild climate regions of south and central Europe, North Africa and West Asia. About four species have seen introduced into India and one of them Cytisus scoparius Link (Family - Leguminosae) is now fairly common in the Nilgiri and Simla hills. In ethnomedical information, this plant used for diuretics, hypnotic \& sedative [10], diabetes [11] and liver disease [12]. Pharmacological studies have confirmed its uterine stimulant effect [13] and anti spasmodic activity [14]. It has also been found to have diuretic activity, hypotensive activity [14] and estrogenic effect. The plant Cytisus scoparius contains the flavone such as 6" O acetyl scoparin [15], flavonals namely rutin, quercetin, quercitrin, isorhamnetin and kaempferol [16] and some isoflavones like genistein and sarothamnoside [17]. Quinolizidine alkaloids namely spartein, sarothamine and lupanine [18] and Benzenoid compounds like tyramine, hydroxyl tyramine [19], phenyl ethanol and cresol [20] have also been reported to be present in the plant. Most of the reported biological activities and active constituents of this plant may be related to its antioxidant nature. Based on this idea the in vitro antioxidant activity of the extracts of aerial part of Cytisus scoparius has been evaluated and reported hereunder.

\section{Methods}

\section{Chemicals}

Rutin was obtained from Acros organics, New Jersy, USA. DPPH (1, 1-diphenyl, 2-picryl hydrazyl), NBT (Nitro blue tetrazolium), NADH (Nicotinamide adenine dinucleotide phosphate reduced), PMS (Phenazine methosulphate), TCA (Trichloro acetic acid), Ferric chloride and BHT (Butylated hydroxy toluene) were obtained from Sigma chemical co USA. Ascorbic acid, curcumin and Vitamin E were obtained from SD Fine chem. Ltd, Biosar, India. TBA (Thiobarbituric acid) and pyridine were obtained from Loba chemie, Mumbai, India. EDTA (Ethylene diamine tetra acetic acid) and Hydrogen peroxide $\left(\mathrm{H}_{2} \mathrm{O}_{2}\right)$ were obtained from Qualigens Fine chemicals, Mumbai, India. Naphthyl ethylene diamine dihydrochloride was obtained from Roch-light ltd, Suffolk, England. Sodium nitro prusside was obtained from Ranbaxy lab, Mohali, India. Pottassium ferric cyanide was obtained from May and Backer, Dagenham, UK. 2-deoxy-2- ribose was obtained from Fluka (Buchs, Switzerland).

\section{Plant material}

Aerial parts of Cytisus scoparius was collected in Nilgiri hills, Tamilnadu region and authenticated through Government Arts College, Ooty. Voucher specimen (SNPS011/ 2003-2004) of this plant material has been retained in the School of Natural Product Studies, Jadavpur University, India.

\section{Extraction}

The aerial part of Cytisus scoparius plant was dried at room temperature and reduced to coarse powder. This powder was extracted with mixture of ethanol: water (7:3 ratio) for 48 hours. The solvent was completely removed by rotary evaporator and further removal of water was carried out by freeze drying. The dried extract was stored in vacuum desiccator for further use.

\section{DPPH radical scavenging activity}

The free radical scavenging capacity of the extracts was determined using DPPH. A methanol DPPH solution $(0.15 \%)$ was mixed with serial dilutions $(0.5 \mu \mathrm{g}$ to $8 \mu \mathrm{g})$ of Cytisus scoparius extracts and after $10 \mathrm{~min}$, the absorbance was read at $515 \mathrm{~nm}$ using a spectrophotometer (Perkin - Elmer Lambda 20 UV - visible spectrophotometer). Vitamin $\mathrm{C}$ used as a standard. The inhibition curve was plotted and $\mathrm{IC}_{50}$ values obtained [21].

\section{Nitric oxide radical inhibition assay}

Nitric oxide radical inhibition can be estimated by the use of Griess Illosvoy reaction [22]. In this investigation,

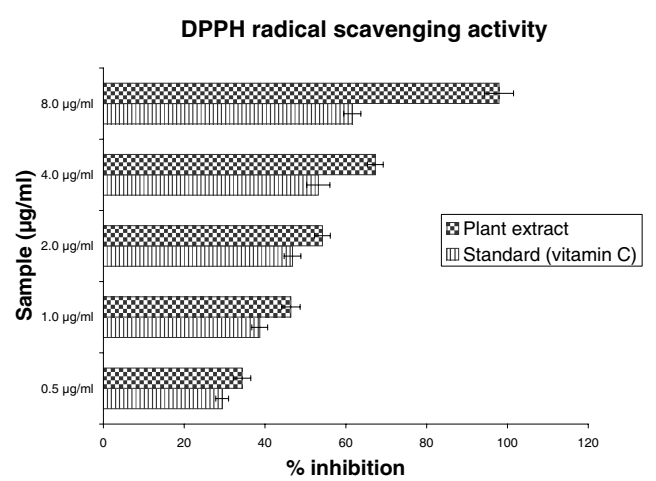

Figure I

Scavenging effect of Cytisus scoparius extract and standard vitamin C on I, I'-Diphenyl-2-picryl hydrazyl (DPPH) radical. Results are mean \pm S.D of five parallel measurements. 


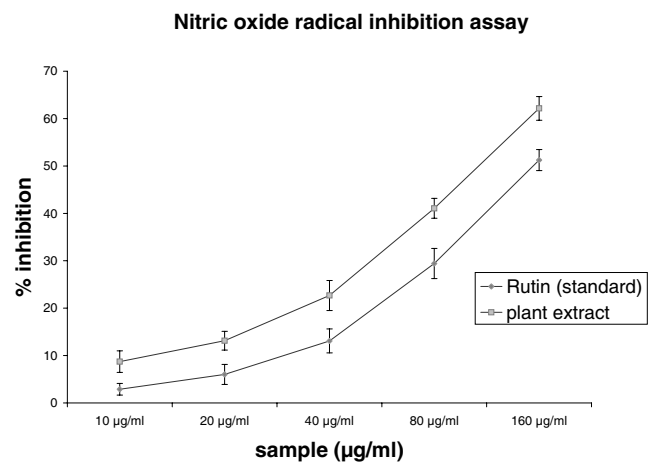

Figure 2

Scavenging effect of Cytisus scoparius extract and standard rutin on Nitric oxide radical. Results are mean \pm S.D of five parallel measurements.

Griess Illosvoy reagent was modified by using naphthyl ethylene diamine dihydrochloride $(0.1 \% \mathrm{w} / \mathrm{v})$ instead of 1 -napthylamine $(5 \%)$. The reaction mixture $(3 \mathrm{ml})$ containing sodium nitroprusside $(10 \mathrm{mM}, 2 \mathrm{ml})$, phosphate buffer saline $(0.5 \mathrm{ml})$ and Cytisus scoparius extract $(10 \mu \mathrm{g}$ to $160 \mu \mathrm{g}$ ) or standard solution (rutin, $0.5 \mathrm{ml}$ ) was incubated at $25^{\circ} \mathrm{C}$ for $150 \mathrm{~min}$. After incubation, $0.5 \mathrm{ml}$ of the reaction mixture mixed with $1 \mathrm{ml}$ of sulfanilic acid reagent $(0.33 \%$ in $20 \%$ glacial acetic acid) and allowed to stand for $5 \mathrm{~min}$ for completing diazotization. Then, $1 \mathrm{ml}$ of naphthyl ethylene diamine dihydrochloride was added, mixed and allowed to stand for $30 \mathrm{~min}$ at $25^{\circ} \mathrm{C}$. A pink coloured chromophore is formed in diffused light. The absorbance of these solutions was measured at $540 \mathrm{~nm}$ against the corresponding blank solutions. Rutin used as a standard.

\section{Superoxide anion scavenging activity}

Measurement of superoxide anion scavenging activity of Cytisus scoparius was done based on the Nishimiki method [23]. About $1 \mathrm{ml}$ of nitroblue tetrazolium (NBT) solution (156 $\mu \mathrm{M}$ NBT in $100 \mathrm{mM}$ phosphate buffer, $\mathrm{pH} 7.4) 1 \mathrm{ml}$ NADH solution $(468 \mu \mathrm{M}$ in $100 \mathrm{mM}$ phosphate buffer, $\mathrm{pH} 7.4$ ) and $0.1 \mathrm{ml}$ of sample solution of Cytisus scoparius $(1.25 \mu \mathrm{g}$ to $10 \mu \mathrm{g})$ in water were mixed. The reaction started by adding $100 \mu \mathrm{l}$ of phenazine methosulphate (PMS) solution $(60 \mu \mathrm{M}$ PMS in $100 \mathrm{mM}$ phosphate buffer, $\mathrm{pH} 7.4$ ) to the mixture. The reaction mixture was incubated at $25^{\circ} \mathrm{C}$ for $5 \mathrm{~min}$, and the absorbance at 560 $\mathrm{nm}$ was measured against blank samples. Decreased absorbance of the reaction mixture indicated increased superoxide anion scavenging activity. Curcumin was used as a positive control.

\section{Lipid peroxidation assay}

The rat liver microsomal fraction was prepared by the method of Bouchet et al [24]. The reaction mixture contained in a final volume of $1.0 \mathrm{ml}, 500 \mu \mathrm{l}$ of liver microsomal fraction, $300 \mu \mathrm{l}$ buffer containing the plant extract $(50-150 \mu \mathrm{g}), 100 \mu \mathrm{l}$ of $\mathrm{FeCl}_{3}(1 \mathrm{mM})$ and $100 \mu \mathrm{l}$ ascorbic acid $(1 \mathrm{mM})$ to start peroxidation. Samples were incubated at $37^{\circ} \mathrm{C}$ for 1 hour, after that lipid peroxidation was measured using the reaction with thiobarbituric acid (TBA). Thiobarbituric acid reactive substances were determined by the methods of Houghton and Aruoma $[25,26]$. The absorbance of the organic layer was measured at 532 $\mathrm{nm}$. All reactions were carried out in triplicate. Vitamin E used as a standard.

\section{Hydroxyl radical scavenging assay}

The assay was performed as described by Halliwell method [27] with minor changes. All solutions were prepared freshly. $1.0 \mathrm{ml}$ of the reaction mixture contained $100 \mu \mathrm{l}$ of $28 \mathrm{mM}$ 2-deoxy-2-ribose (dissolved in phosphate buffer, $\mathrm{pH} 7.4), 500 \mu \mathrm{l}$ solution of various concentrations of the Cytisus scoparius ( 10 to $80 \mu \mathrm{g}$ ), $200 \mu \mathrm{l}$ of 200 $\mu \mathrm{M} \mathrm{FeCl}_{3}$ and $1.04 \mathrm{mM}$ EDTA ( $\left.1: 1 \mathrm{v} / \mathrm{v}\right), 100 \mu \mathrm{H} \mathrm{H}_{2} \mathrm{O}_{2}(1.0$ $\mathrm{mM})$ and $100 \mu \mathrm{l}$ ascorbic acid $(1.0 \mathrm{mM})$. After an incubation period of 1 hour at $37^{\circ} \mathrm{C}$ the extent of deoxyribose degradation was measured by the TBA reaction $[23,24]$. Measure the absorbance at about $532 \mathrm{~nm}$ against the blank solution. Vitamin E was used as a positive control.

\section{Reducing power}

The reducing power of Cytisus scoparius was determined according to the Oyaizu method [28]. Different concentration of Cytisus scoparius extract $(100 \mu \mathrm{g}-1000 \mu \mathrm{g})$ in 1

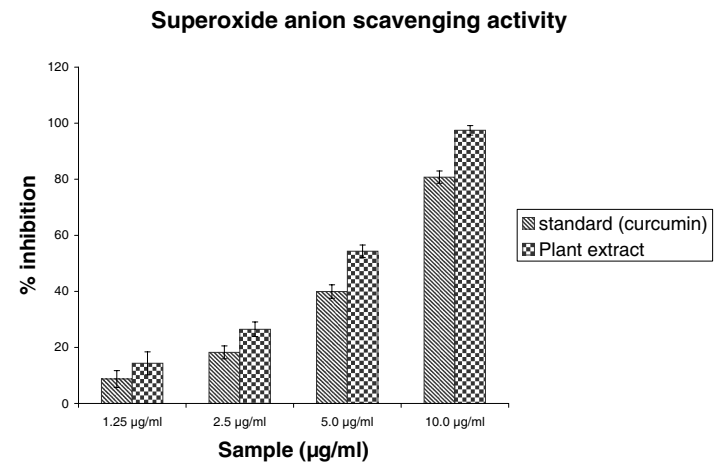

\section{Figure 3}

Effect of Cytisus scoparius extract and curcumin on scavenging of superoxide anion radical formation. Results are mean \pm S.D of five parallel measurements. 


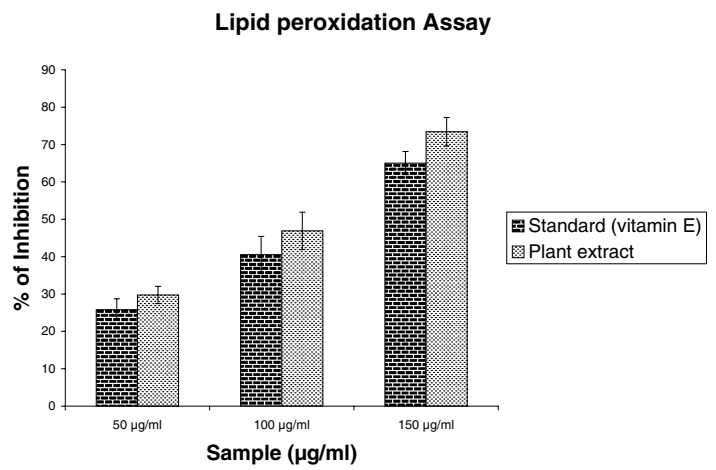

Figure 4

Effect of Cytisus scoparius extract and vitamin E on lipid peroxidation of liver microsome induced by $\mathrm{Fe}^{2+}$ /ascorbate. Results are mean \pm S.D of five parallel measurements.

$\mathrm{ml}$ of distilled water was mixed with phosphate buffer (2.5 ml, $0.2 \mathrm{M}, \mathrm{pH}$ 6.6) and potassium ferricyanide $\left[\mathrm{K}_{3} \mathrm{Fe}(\mathrm{CN})_{6}\right](2.5 \mathrm{ml}, 1 \%)$. The mixture was incubated at $50^{\circ} \mathrm{C}$ for $20 \mathrm{~min}$. A portion $(2.5 \mathrm{ml})$ of trichloroacetic acid $(10 \%)$ was added to the mixture, which was then centrifuged at $3000 \mathrm{rpm}$ for $10 \mathrm{~min}$. The upper layer of the solution $(2.5 \mathrm{ml})$ was mixed with distilled water $(2.5 \mathrm{ml})$ and $\mathrm{FeCl}_{3}(0.5 \mathrm{ml} .0 .1 \%)$ and the absorbance was measured at $700 \mathrm{~nm}$. Increased absorbance of the reaction mixture indicated increased reducing power. Butylated hydroxy toluene used as a standard.

\section{Determination of total phenolic compounds}

Total soluble phenolic in the aqueous extract of Cytisus scoparius were determined with Folin-Ciocalteu reagent according to the standard method [29] using pyrocatechol as a standard. Briefly, $0.1 \mathrm{ml}$ of extract solution (contains $1000 \mu \mathrm{g}$ extract) in a volumetric flask diluted distilled water $(46 \mathrm{ml})$. About $1 \mathrm{ml}$ of Folin - Ciocalteu reagent was added and the contents of the flask mixed thoroughly. After $3 \mathrm{~min}, 3 \mathrm{ml}$ of $\mathrm{Na}_{2} \mathrm{Co}_{3}(2 \%)$ was added, then the mixture was allowed to stand for 2 hour with intermittent shaking. The absorbance was measured at $760 \mathrm{~nm}$. The concentration of total phenolic compounds in the Cytisus scoparius determined as microgram of pyrocatechol equivalent by using an equation that was obtained from Gulcin et al [30]. The equation is given below:

Absorbance $=0.001 \times$ Pyrocatechol $(\mu \mathrm{g})+0.0033$

\section{Statistical analysis}

All the invitro experimental results were mean \pm S.D of five parallel measurements.

\section{Results}

\section{DPPH radical scavenging activity}

The hydro alcoholic extract of Cytisus scoparius exhibited a significant dose dependent inhibition of DPPH activity, with a $50 \%$ inhibition $\left(\mathrm{IC}_{50}\right)$ at a concentration of $1.5 \mu \mathrm{g} /$ $\mathrm{ml}$. The result was mentioned in figure 1 . The $\mathrm{IC}_{50}$ value of the extract was found to be lesser than the standard, vitamin $\mathrm{C}\left(\mathrm{IC}_{50} 3.0 \mu \mathrm{g} / \mathrm{ml}\right)$.

\section{Nitric oxide radical inhibition assay}

The scavenging of nitric oxide by plant extract was increased in a dose-dependent manner as illustrated in figure 2. At concentration of $116.0 \mu \mathrm{g} / \mathrm{ml}$ of extract $50 \%$ of nitric oxide generated by incubation was scavenged. This $\mathrm{IC}_{50}$ value of extract found to be lesser than the standard, rutin $\left(\mathrm{IC}_{50} 160.0 \mu \mathrm{g} / \mathrm{ml}\right)$.

\section{Superoxide anion scavenging activity}

The superoxide anion derived from dissolved oxygen by Phenazine methosulphate/NADH coupling reaction reduces nitro blue tetrazolium. The decrease the absorbance at $560 \mathrm{~nm}$ with the plant extract thus indicates the consumption of superoxide anion in the reaction mixture. As mentioned in figure 3, the plant extract as well as curcumin showed the scavenging activity; $\mathrm{IC}_{50}$ values, $4.7 \mu \mathrm{g} /$ $\mathrm{ml}$ and $5.84 \mu \mathrm{g} / \mathrm{ml}$, respectively.

\section{Lipid peroxidation assay}

Activity of plant extract against non-enzymatic lipid peroxidation in rat liver microsomes has been shown in figure 4. Addition of $\mathrm{Fe}^{2+}$ /ascorbate to the liver microsomes cause increase in lipid peroxidation. The extract showed inhibition of peroxidation effect in all concentrations,

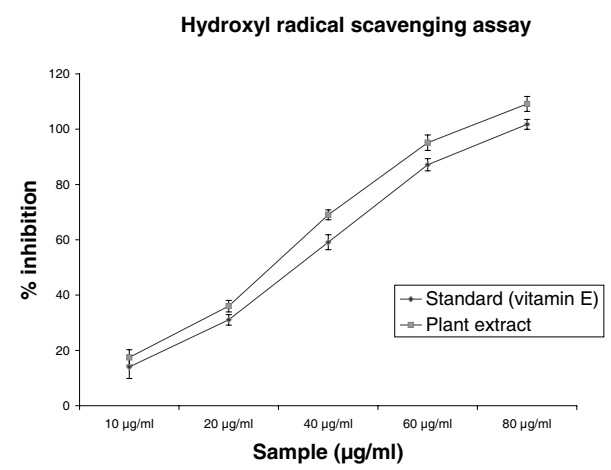

Figure 5

Effect of Cytisus scoparius extract and vitamin E on deoxyribose degradation assay. Results are mean \pm S.D of five parallel measurements. 


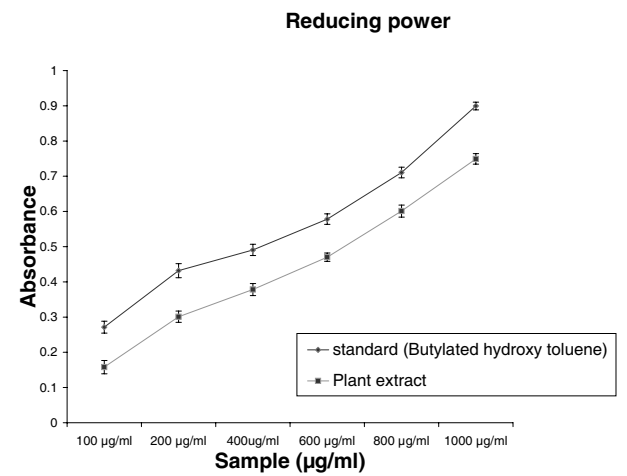

\section{Figure 6}

The reductive ability of Cytisus scoparius extract and butylated hydroxy toluene. Results are mean \pm S.D of five parallel measurements.

which showed 50\% inhibition effect at $104.0 \mu \mathrm{g} / \mathrm{ml}$. The extract inhibition value was found to be lesser than the standard, vitamin E $\left(\mathrm{IC}_{50} 120.5 \mu \mathrm{g} / \mathrm{ml}\right)$

\section{Hydroxyl radical scavenging assay}

To attack the substrate deoxyribose hydroxyl radicals were generated by reaction of Ferric-EDTA together with $\mathrm{H}_{2} \mathrm{O}_{2}$ and ascorbic acid. When the plant extract were incubated with the above reaction mixture, it could prevent the damage against sugar. The results are shown in figure 5, the concentrations of $50 \%$ inhibition were found to be 27.0 $\mu \mathrm{g} / \mathrm{ml}$ and $32.5 \mu \mathrm{g} / \mathrm{ml}$ for the extract and standard of vitamin $\mathrm{E}$, respectively. The extract inhibition value was found to be lesser than the standard

\section{Reducing power}

Figure 6 shows the reductive capabilities of the plant extract compared to butylated hydroxy toluene. The reducing power of extract of Cytisus scoparius was very potent and the power of the extract was increased with quantity of sample. The plant extract could reduce the most $\mathrm{Fe}^{3+}$ ions, which had a lesser reductive activity than the standard of butylated hydroxy toluene.

\section{Determination of total phenolic compounds}

The total phenolic contents of hydro alcoholic extract of Cytisus scoparius was $0.0589 \mu \mathrm{g}$ pyrocatechol equivalent / $\mathrm{mg}$.

\section{Discussion}

Free radicals have aroused significant interest among scientists in the past decade. Their broad range of effects in biological systems has drawn the attention of many exper- imental works. It has been proved that these mechanisms may be important in the pathogenesis of certain diseases and ageing. There are many reports that support the use of antioxidant supplementation in reducing the level of oxidative stress and in slowing or preventing the development of complications associated with diseases [31]. Many synthetic antioxidant components have shown toxic and/or mutagenic effects, which have shifted the attention towards the naturally occurring antioxidants. Numerous plant constituents have proven to show free radical scavenging or antioxidants activity [32]. Flavonoids and other phenolic compounds (hydroxyl cinnamic derivatives, catechines etc) of plant origin have been reported as scavengers and inhibitors of lipid peroxidation [33].

In our present study demonstrated that, $\mathrm{DPPH}$ is a free radical, stable at room temperature, which produces a purple colour solution in methanol. It is reduced in the presence of an antioxidant molecule, giving rise to uncoloured methanol solutions. Figure 1 illustrates the decrease in the concentration of DPPH radical due to scavenging ability of hydro alcoholic extract of plant and vitamin C, which is comparable to the reported value of Thabrew et al [34]. Nitric oxide radical inhibition study proved that aerial part of the extract is a potent scavenger of nitric oxide. This nitric oxide generated from sodium nitro prusside reacts with oxygen to form nitrite. The extract inhibits nitrite formation by competing with oxygen to react with nitric oxide directly and also to inhibit its synthesis. Scavengers of nitric oxide compete with oxygen leading to reduced production of nitric oxide [35]. From the nitric oxide test, rutin was used as a standard. The $\mathrm{IC}_{50}$ value of the rutin is comparable to the reported value of Badami et al [36].

In the PMS/NADH -NBT system, superoxide anion derived from dissolved oxygen by PMS/NADH coupling reaction reduces NBT. The decrease of absorbance at 560 $\mathrm{nm}$ with antioxidants thus indicates the consumption of superoxide anion in the reaction mixture. Addition of various concentrations of extract as well as curcumin (standard) in above coupling reaction showed decrease in absorbance. The antioxidant property of curcumin is generally attributed to its phenolic nature [37]. Sreejayan and Rao et al [38] have earlier observed that for superoxide and DPPH scavenging, the order of activity was: curcumin $>$ demethoxycurcumin $>$ bisdemethoxycurcumin $>$ diacetylcurcumin (almost inactive). The liver microsomal fraction undergoes rapid non-enzymatic peroxidation when incubated with $\mathrm{FeCl}_{3}$ and ascorbic acid. The use of Fe (III) in the presence of a reducing agent such as ascorbate produces .OH [39] and they attack the biological material. This leads to the formation of MDA (malonodialdehyde) and other aldehydes, which form a pink chromogen with 
TBA, absorbing at $532 \mathrm{~nm}$ [40]. The extract and vitamin E exhibited strong scavenging effect of hydroxyl radical which could inhibit lipid damage at different concentration. The scavenging effect of vitamin $\mathrm{E}$ is in accordance with the report of Hemanth et al [41]. The extract was examined for its ability to act as .OH radical scavenging agent. Ferric EDTA was incubated with $\mathrm{H}_{2} \mathrm{O}_{2}$ and ascorbic acid at PH -7.4; hydroxyl radicals were formed in free solution and were detected by their ability to degrade 2deoxy-2- ribose into fragments that on heating with TBA at low $\mathrm{pH}$ form a pink chromogen [26,27]. When Cytisus scoparius plant extract and vitamin $\mathrm{E}$ were added to the reaction mixture they removed hydroxyl radicals and prevented the degradation of 2-deoxy-2-ribose as mentioned above. The observed $\mathrm{IC}_{50}$ values of the extract and Vitamin E were analogous to the reported values of Sen et al [42]. Figure 6 shows the reductive capabilities of plant extract compared with butylated hydroxy toluene. For the measurements of the reductive ability, we investigated the $\mathrm{Fe}^{3+}$ to $\mathrm{Fe}^{2+}$ transformation in the presence of hydro alcoholic extract using the method of Oyaizu et al [28]. The reducing power increased with increasing the amount of extract. The reducing capacity of compound may serve as a significant indicator of its potential antioxidant activity [43]. The absorbance values of the extract at different concentrations were found to be less than that of the reference compound. The value of reference compound is in accordance with the report of Illhami et al [44]. The phenolic compounds may contribute directly to anti oxidative action [45]. This result indicates that polyphenol present in aerial part and its extract could be partly responsible for the beneficial effects. Compelling evidence indicates that increased consumption of dietary antioxidants or fruits and vegetables with antioxidant properties may contribute to the improvement in quality of life by delaying onset and reducing the risk of degenerative diseases associated with aging. Therapeutic potentials of various Indian medicinal plants of Simla hills are well documented from its traditional origin in different aspects $[46,47]$. These plant species require to be further explored for the possible molecular mechanisms which are underway at our laboratory.

\section{Conclusion}

This study suggested that the Cytisus scoparius. L plant extract possess antioxidant activity, which might be helpful in preventing or slowing the progress of various oxidative stress- related diseases. Further investigation on the isolation and identification of antioxidant component(s) in the plant may lead to chemical entities with potential for clinical use.

\section{Competing interests}

The author(s) declare that they have no competing interests.

\section{Authors' contributions}

SR: Performed the study

KFHN: Performed the study

VK: Performed the study

KM: Design, analysis and acquisition of data

BPS: Helped to perform the study

AB: Helped to perform the study

PKM: Supervised the study design along with drafting the manuscript.

\section{Acknowledgements}

Financial assistance from All India Council for Technical Education through AICTE - QIP (Quality Improvement Programme) Project is gratefully acknowledged.

\section{References}

I. Freeman BA, Crapo JD: Biology of Diseases. Free radicals and tissue injury. Lab Invest 1982, 47:4I 2-426.

2. Maxwell SR, Lip GY: Free radicals and antioxidants in cardiovascular disease. Br J Clin Pharmacol 1997, 44:307-317.

3. Pryor WA: Free radical reactions and their importance in biochemical systems. Fed Proc 1973, 32:1862-1869.

4. Sato M, Ramarathnam N, Suzuki Y, Ohkubo T, Takeuchi M, Ochi H: Varietal differences in the phenolic content and superoxide radical scavenging potential of wines from different sources. J Agric Food Chem 1996, 44:37-4I.

5. Stajner D, Milic N, Mimica-Dukic N, Lazic B, lgic R: Antioxidant abilities of cultivated and wild species of garlic. Phytother Res 1998, | 2:5|3-5|4.

6. Sanchez-Moreno C, Larrauri JA, Saura-Calixto F: Free radical scavenging capacity an inhibition of lipid oxidation of wines, grape juices and related polyphenolic constituents. Food Res Int 1999, 32:407-4I2.

7. Mukherjee PK: Pharmacological screening of herbal drugs. In Quality Control of Herbal Drugs - An Approach to Evaluation of Botanicals Business Horizons, and New Delhi, India; 2002:519-582.

8. Malencic D, Gasic O, Popovic M, Boza P: Screening for antioxidant properties of Salvia reflexa hornem. Phytother Res 2000, 14:546-548.

9. Costantino L, Albasini A, Rastelli G, Benvenuti S: Activity of polyphenolic crude extracts as scavengers of superoxide radicals and inhibitors of xanthine oxidase. Planta Med 1992, 58:342-344.

10. Siegel RK: Herbal Intoxication Psycho Active Effects from Herbal Cigarettes, tea, and capsules. J Am Med Assoc 1976, 236(5):473-476.

II. Castro VR: Chromium in a Series of Portuguese plants used in the herbal treatment of diabetes. Biol Trace Elem Res 1998, 62:101-106.

12. Rivera D, Obon C: The Ethnopharmacology of Maderia and Portosanto islands. a Review. J Ethnopharmacol 1995, 46(2):73-93.

13. Joachimovits R: About a New Uterotonic. Zentralbl Fur Gynecol 1935, 59:39.

14. Bhakuni DS, Dhar ML, Dhar MM, Dhawan BN, Mehrotra BN: Screening of Indian plants for biological activity. Part-II. Indian J Exp Biol 1969, 7:250-262.

15. Brum-Bousquet M, Tillequin F, Paris RR: From the twigs of Sarothamnus scoparius koch has been isolated a new C-Glycosyl flavone: The 6" -O acetyl scoparin. Lloyd 1977, 40(6):59I.

16. Brum-Bousquet M, Paris RR: Flavonoids of Common Broom (Sarothamnus scoparius). Bull Liais Group Polyphen 1974, 5:34. 
17. Viscardi P, Reynaud J, Raynaud J: A New Isoflavone Glycoside from the Flowers of Cytisus scoparius Link. (Leguminosae). Pharmazie 1984, 39: I I-781.

18. Wink M, Witte L, Hartmann T: Quinolizidine alkaloid composition of plants and of photomixotropic cell suspension cultures of Sarothamnus and Oronbanche rapum -Genistae. Planta Med I 981, 43:342-352.

19. Schmalfuss $H$, Heider A: Tyramine hydroxy tyramine, the blood-pressure-raising substances of the pod of the common broom Sarothamnus scoparius Wimm. Biochem Z 1931, 236:226-230.

20. Kurhara T, Kikuchi M: Studies of the Constituents of Flowers. XIII. On the components of the flower of Cytisus scoparius 1980, 100:1054-1057.

21. Viturro C, Molina A, Schmeda-Hischmann G: Free radical scavengers from Mutisia friesiana (Asteraceae) and Sanicula graveolens (Apiaceae). Phytother Res 1999, 13:422-424.

22. Garrat DC: The Quantitative analysis of Drugs. Chapman and Hall Itd, Japan 1964, 3:456-458.

23. Nishimiki M, Appaji N, Yagi K: The occurrence of superoxide anion in the reaction of reduced phenazine mehosulphate and molecular oxygen. Biochem Biophys Res Commun 1972, 46:849-854.

24. Bouchet N, Barrier L, Fauconneau B: Radical Scavenging activity and antioxidant properties of tannins from Guiera senegalensis (Combretaceae). Phytother Res 1998, I 2:159-162.

25. Houghton PJ, Zarka R, De la Heras B, Hoult JR: Fixed oil of Nigella sativa and derived thymoquinone inhibit eicosanoid generation in leukocytes and membrane lipid peroxidation. Planta Med 1995, 61:33-36.

26. Aruoma OI, Laughton MJ, Halliwell B: Carnosine, homocarnosine and anserine; could they act as antioxidants in-vivo? Biochem J 1989, 264:863-869.

27. Halliwell B, Gutteridge JM, Aruoma OI: The deoxyribose method: a simple 'test tube' assay for determination of rate constants for reaction of hydroxyl radicals. Anal Biochem 1987, 165:215-219.

28. Oyaizu M: Studies on product of browning reaction prepared from glucose amine. Jap J Nutr 1986, 44:307-315.

29. Slinkard K, Singleton VL: Total Phenol analyses: automation and comparison with manual methods. Am J Enol Viticult 1977, 28:49-55.

30. Gulcin I, Oktay M, Kufrevioglu OI, Aslan A: Determination of antioxidant activity of lichen Cetraria islandica (L) Ach. J Ethnopharmacol 2002, 79:325-329.

31. Rose WM, Creighton MO, Stewart DHPJ, Sanwal M, Trevithick GR. In vivo effects of vitamin $E$ on cataractogenesis in diabetic rats. Can J Ophtalmol 1982, 17:6I-66.

32. Aruoma Ol, Cuppett SL: Antioxidant methodology In vivo and In vitro concepts. AOCS press, Champaign, Illinois; 1997:4I-I72.

33. Formica JV, Regelson W: Review of the biology of quercetin and related biflavonoids. Food chem Toxicol 1995, 33:106I-1080.

34. Thabrew MI, Hughes RD, Mc Farlane IG: Antioxidant activity of Osbeckia aspera. Phytother Res 1998, I 2:288-290.

35. Marcocci L, Packer L, Droy-Lefai MT, Sekaki A, Gardes-Albert M: Antioxidant action of Ginkgo biloba extracts EGb 76I. Methods Enzymol 1994, 234:462-475.

36. Badami S, Moorkoth S, Rai SR, Kannan E, Bhajraj S: Antioxidant activity of caesalpinia sappan Heartwood. Biol Pharm Bull 2003, 26(I I): I534-I537.

37. Toda S, Ohnishi M, Kimura M, Nakashima I: Action of curcuminoids on the hemolysis and lipid peroxidation of mouse erythrocytes induced by hydrogen peroxide. J Ethnopharmacol 1988, 23:105-106.

38. Sreejayan, Rao MNA: Nitric oxide scavenging by curcuminoids. J Pharm Pharmacol 1997, 49:105-107.

39. Aruoma OI.: Characterization of drugs as antioxidant prophylactics. Free Rad Biol Med 1996, 20(5):675-705.

40. Kosugi $\mathrm{H}, \mathrm{Kato} \mathrm{T}$, Kikugawa $\mathrm{K}$ : Formation of yellow, orange and red pigments in the reaction of alk-2-enals with 2-thiobarbituric acid. Anal Biochem 1987, 165:456-464.

41. Jadav HR, Bhutani KK: Antioxidant properties of Indian medicinal plants. Phytother Res 2002, 16:77|-773.

42. Sen T, Dhara AK, Bhattacharjee S, Pal S, Nag Chaudhuri AK: Antioxidant activity of the methanol fraction of Pluchea indica root extract. Phytother Res 2002, 16:331-335.
43. Meir S, Kanner J, Akiri B, Hadas SP: Determination and involvement of aqueous reducing compounds in oxidative defense systems of various senescing leaves. J Agric Food Chem 1995, 43:1813-1817.

44. Gulcin I, Oktay M, Kufrevioglu OI, Aslan A: Determination of antioxidant activity of lichen Cetraria islandica (L) Ach. J Ethnopharmacol 2002, 79:325-329.

45. Duh PD, Tu YY, Yen GC: Antioxidant activity of aqueous extract of harnjyur (Chyrsanthemum morifolium Ramat). Lebensm wiss Technol 1999, 32:269-277.

46. Mukherjee PK: GMP for Indian system of medicine. In GMP for Botanicals - Regulatory and quality issues on Phytomedicines Edited by: Mukherjee PK, Verpoorte R. Business Horizons, New Delhi, India; 2003:99-112.

47. Rajan S, Seturaman M, Mukherjee PK: Ethnobiology of the Nilgiri hills, India. Phytother Res 2002, 16:98-116.

\section{Pre-publication history}

The pre-publication history for this paper can be accessed here:

http://www.biomedcentral.com/1472-6882/6/8/prepub
Publish with Biomed Central and every scientist can read your work free of charge

"BioMed Central will be the most significant development for disseminating the results of biomedical research in our lifetime. "

Sir Paul Nurse, Cancer Research UK

Your research papers will be:

- available free of charge to the entire biomedical community

- peer reviewed and published immediately upon acceptance

- cited in PubMed and archived on PubMed Central

- yours - you keep the copyright

Submit your manuscript here:

http://www.biomedcentral.com/info/publishing_adv.asp
BioMedcentral 